\title{
枝管の圧力脈動低減効果に関する一考察*
}

\author{
石原国彦*1, 森口裕一*2, 西川和男*2
}

\section{A Consideration of Reduction Effect of Side Branch on Pressure Fluctuation}

\author{
Kunihiko ISHIHARA*3, Yuich MORIGUCHI and Kazuo NISHIKAWA \\ ${ }^{* 3}$ Kawasaki Heavy Industries, Ltd., Technical Institute, \\ 1-1 Kawasaki-cho, Akashi-shi, Hyogo, 673-8666 Japan
}

Pressure fluctuation occurs in an oil pressure pump in the nature of the machine. It becomes a cause of a vibration and a noise of a building where the oil pressure pump are set because the pressure fluctuation gives a fluctuating force on floors and walls of the building. So it is important to reduce the vibration and noise from an environmental point of view. A side-branch is often used to reduce the pressure fluctuation because of its simplicity and its effectiveness. In this paper, the side-branches are applied to the real pumps and the reduction effects are described. As 2nd and 3rd harmonics of the pressure fluctuation are dominant in this pump, two side-branches are used to reduce each harmonics components respectively. As a result, the vibration of wall and the interior noise of the room were suppressed violently. And it was clarified that the reduction mechanism is not resonance but the superposition of two fluctuating weves which are the progressive and reflective waves.

Key Words: Hydraulic Equipment, Measurement and Control, Pressure Wave, Noise, Pipe Line, Side-branch, Reduction Effect, Vibration

\section{1. まえがき}

油圧ポンプや往復動圧縮機では機械の特性として圧力 脈動が発生する。圧力脈動を生じる流体用配管系など では, その脈動によって配管の支持点から建屋の床に 振動（力）が伝わり, 建屋の壁や天井, 床を振動させ, それが原因で大きな騒音を発生させる場合がある。そ こで, 起振源である圧力脈動を低減させるために, 主 配管に枝管を設けたり，共鳴型消音器を設けたりする 手段が採用されている。しかし共鳴型消音器は構造が 枝管に比べ複雑であり，チューニングも難しいため, 枝管ほどには使われていない。

枝管は構造が簡単であるとともに，反射波の位相を主 配管からの分岐部において反転(180 度位相を変える)さ せ主配管の脈動と波動的に干渉させて相殺し, 脈動を 低減させるという簡単なメカニズムのため多用されて いる.

枝管の減衰性能については多くのテキストで述べられ て抢り (1) - (2), その評価法として透過損失 (Transmission Loss, 略して TL) と挿入損失 (Insertion loss, 略して IL) の二つが与えられている。しかしながら両 者とも枝管前後の圧力脈動の比を調べるだけでは求ま らない值であるため, 実用的で信頼性のある評価方法 は十分確立されていないようである.小嶋らはこのよ うな観点から圧力脈動の伝達特性を測定し, 減衰性能 を適切に評価する手法を開発した ${ }^{(3)}$ ～(4). さらに小嶋

* 原稿受付 2003 年 3 月 12 日。

*1 正員, 川崎重工業(株)技術研究所(恶 673-8666 明石市川崎 町 1-1)。

*2 川崎重工業(株)機械ビジネスセンター(严650-8670 神戸市 中央区東川崎町 3-1).

E-mail : isihara@ati.khi.co.jp
らは枝管の欠点である狭帯域しか効果を持たない問題 を解決するため, 可変共鳴モード形の枝管を開発した ${ }^{(5)}$. しかしながら枝管を実機に適用し，劇的な効果を得た 例はあまり見られない。また，枝管の圧力脈動低減入 カニズムは良く知られているものの実験デー夕に基づ き示した例は少ない。さらにある周波数で効果のある 枝管では, その 2 倍の周波数では共鳴し非常に大きい 負の効果となると信じられている節もある.

あるプラントの設計事前検討において油圧ポンプの 脈動に起因する振動・騒音が懸念されたことから，性 能試験の機会を捕らえて枝管を用いた脈動低減効果の 確認実験を行った。その結果，枝管なしの時は予想ど おり建屋の振動・騒音が大きく，枝管使用時は圧力脈

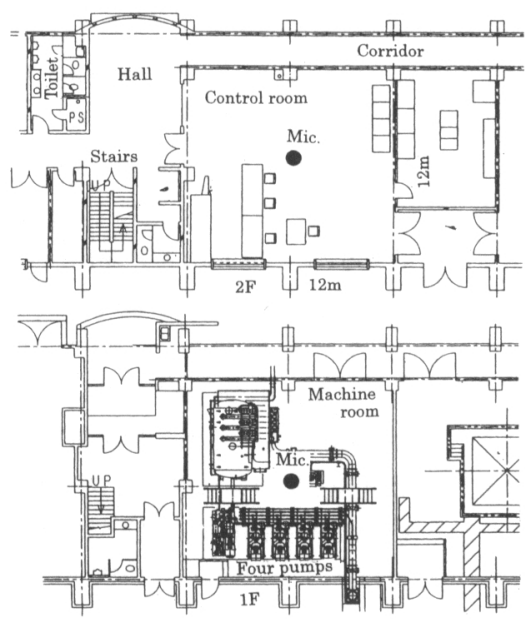

Fig.1 Array of machine and control rooms 


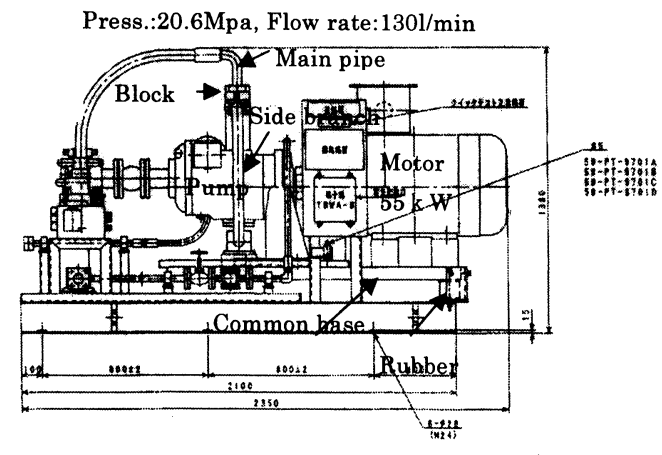

Fig.2 Outline of pump system

動をほとんど消すことができると共に，大きかった建 屋の振動・騷音も大幅に低減できた，本論文では枝管 を実プラントの騒音低減手段として適用した結果につ いて述べると共に, 前述した疑問点に答えるため実測 データに基づき圧力脈動低減メカニズムをより明確に する。

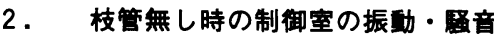

図 1 に油圧ポンプを格納している機械室とその直上 にある制御室の概略を，図 2 に油圧ポンプを示す、4 台 の油圧ポンプが防振支持台に設置されているが，ポン プの吐出配管は床に直付けされている。そのため脈動
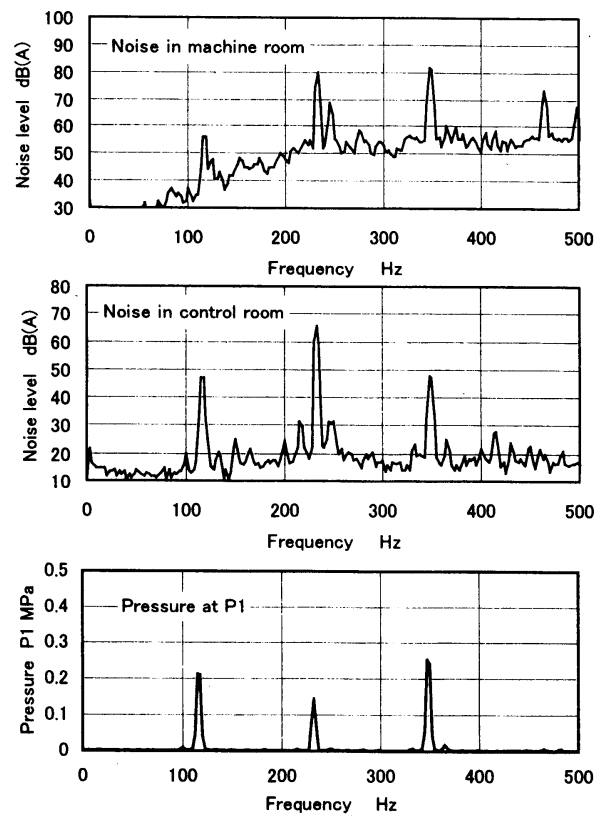

Fig. 3 Spectra of noise and pressure without side branch

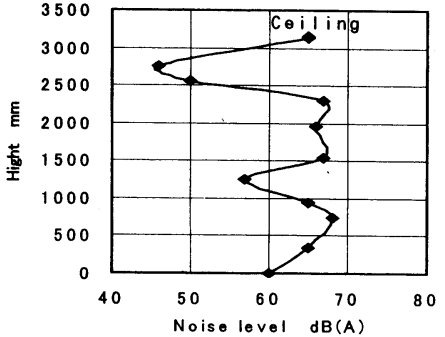

Fig.4 Noise contour of control room

による起振力が床に伝わり，建屋壁を経由して 2 階の 制御室の床，壁および天井を振動させそれが放射音と して室内で $71 \mathrm{~dB}(\mathrm{~A})$ の騷音となった。図 3 にポンプー 台が稼動している場合の機械室内および制御室内のそ れぞれ中央に設置したマイクロホンで計測した騒音ス ペクトルと吐出圧力のスペクトルを示す。この図から 制御室では $230 \mathrm{~Hz}$ の騒音が卓越しており, 騒音の O.A. 值を支配していることがわかる。この周波数成分は油 圧ポンプの 2 次成分 $\left(\mathrm{f}_{2}=2 \mathrm{NZ} / 60=2 \times 985 \times 7 / 60=230 \mathrm{~Hz}\right.$, ここで $\mathrm{N}$ ：回転数 $(\mathrm{rpm}), \mathrm{Z}$ : ピストン数）であり, 圧力計測でも顕著に現われている。一方, 機械室内の 騒音が空気伝播して制御室内の騒音を大きくしている ことも考えられるので, 機械室と制御室間の透過損失 を計測したところ $45 \mathrm{~dB}(230 \mathrm{~Hz})$ もあり，機械室と制 御室の騒音レベル差が $15 \mathrm{~dB}(230 \mathrm{~Hz})$ であることから 空気伝播音は騒音を大きくする原因ではないことがわ かった。さらに制御室内の高さ方向の騒音分布を調べ たところ図 4 のような分布を持ち、約 $230 \mathrm{~Hz}$ (波長約 $1.5 \mathrm{~m})$ で共鳴を起こしていることもわかった.

以上より制御室の騒音過大の原因は油圧ポンプの脈動 成分が床, 壁, 天井を振動させ, そのため振動放射音 が室内に充満し，さらに共鳴まで起こしたためである。

\section{3. 枝管の奻果確証実験}

本実験から制御室内の騒音に最も影響が大きいのは 油圧ポンプの脈動 2 次成分であるが, 1 次および 3 次 成分も無視できないほど大きい. しかし実際問題とな る成分は別途行ったスピーカ試験から 2 次と 3 次成分 であったので，これら 2 つの脈動成分を取り除くこと にした．以下にその結果を示す.

3.1 実験ケース 実験は 2 次用枝管および 2 次用枝 管 +3 次用枝管の 2 種類行い，後者を行うためにブロ ックを図 5 に示すように A と B のポートを有するもの (Long と称す) と，Bのみのポートを有するもの（図 中 2 点鎖線までの長さで Short と称す）の 2 種類製作 した. また対向型（B と B'）と非対向型（B と A）の 圧力脈動低隇効果への影響を調べるため, 枝管取り付 けポートを図のように設けた。実験ケースを表 1 と表 


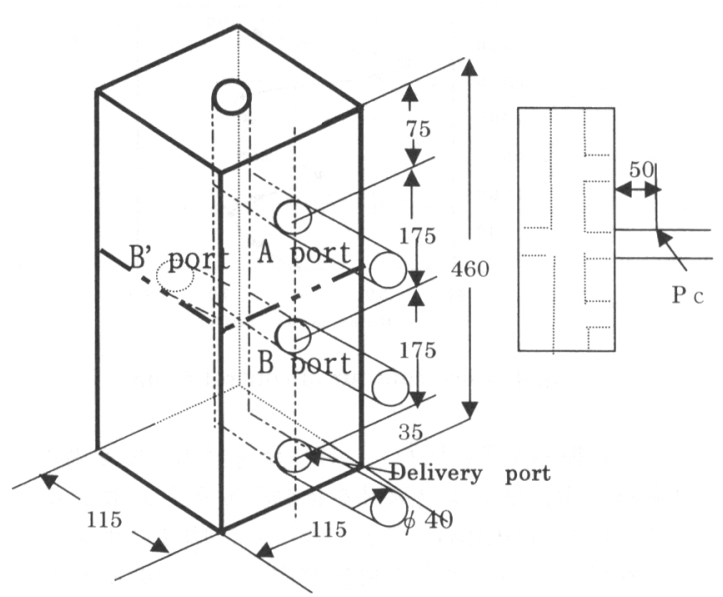

Fig. 5 Block used in this experiment

Table1. Countermeasure with $2^{\text {nd }}$ side-branch

\begin{tabular}{|c|c|c|c|}
\hline Case & Block & Port & Length \\
\hline 1 & Long & B & $1.83 \mathrm{~m}$ \\
\hline 2 & Long & A & $1.83 \mathrm{~m}$ \\
\hline 3 & Short & B & $1.83 \mathrm{~m}$ \\
\hline
\end{tabular}

Table2 Countermeasure with $2^{\text {nd }}+3^{\text {rd }}$ side-branches

\begin{tabular}{|c|c|c|c|c|c|}
\hline Case & \multirow{2}{*}{ Block } & \multicolumn{2}{|c|}{$\begin{array}{c}\text { Side branch for } \\
2^{\text {nd }} \text { component }\end{array}$} & \multicolumn{2}{c|}{$\begin{array}{c}\text { Side branch for } \\
3^{\text {rd }} \text { component }\end{array}$} \\
\cline { 3 - 6 } & & Port & Length & Port & Length \\
\hline 4 & Long & B & $1.83 \mathrm{~m}$ & B' $^{\prime}$ & $1.22 \mathrm{~m}$ \\
\hline 5 & Long & B & $1.83 \mathrm{~m}$ & A & $1.17 \mathrm{~m}$ \\
\hline 6 & Long & B & $1.83 \mathrm{~m}$ & A & $1.22 \mathrm{~m}$ \\
\hline 7 & Long & B & $1.83 \mathrm{~m}$ & A & $1.27 \mathrm{~m}$ \\
\hline
\end{tabular}

2 に示す.

3.2 計測項目

(1) 機械室騷音 (1 点)

(2) 制御室騒音(1 点)

(3) 元圧 $\mathrm{p}_{1}$

(4) 枝管結合部圧力 $\mathrm{p}$ 。

(5) 枝管先端部圧力 $\mathrm{p}_{\mathrm{t}}$

\section{4. 実験結果と考察}

\subsection{2 次用岐管のチューニングと音速の評価}

空気中の音速は常温で $340 \mathrm{~m} / \mathrm{s}$ として一般に用いら れているが, 油の場合は空気の混入度合いにより必ず しも理論値どおりではないことを経験している。しか し枝管を使用する場合はこの音速を正確に把握してお くことが重要であるため, ここでは枝管長さを種々変 えて最も効果の大きい長さから逆に音速を同定した。 図 6 に枝管長さに対する 2 次成分 $(230 \mathrm{~Hz})$ の騷音低減

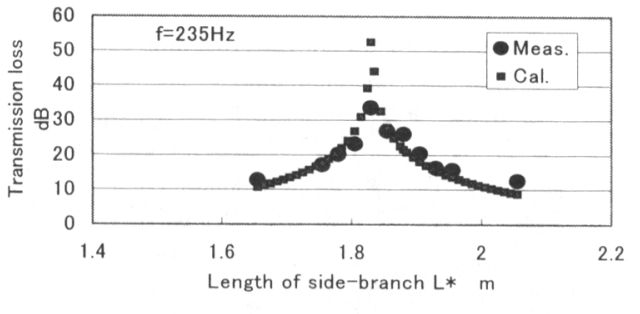

Fig.6 Tuning result
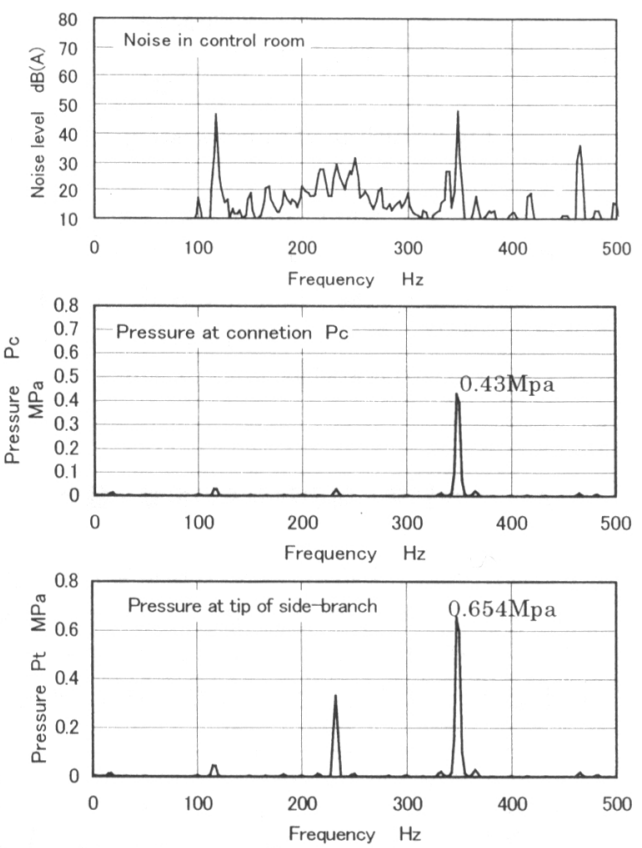

Fig.7 Spectra of noise and pressures with side branch for $2^{\text {nd }}$ component

量の実測值を○印で示す。この図より $\mathrm{L}^{*}=1.83 \mathrm{~m} の$ 時に 最大効果を示した。そこで音速を

$$
c=4 L^{*} f=4 \times 1.83 \times 230=1684 \mathrm{~m} / \mathrm{s}
$$

とした。この值は一般に言われている $1700 \mathrm{~m} / \mathrm{s}$ とほぼ 同じである (6). 図中には式(1)で示す枝管の効果（透 過損失 TL) の理論値を併せて示している ${ }^{(2)}$.

$$
\text { ATT }=10 \log \left\{1+\frac{1}{4}\left(\frac{S_{p}}{S}\right)^{2} \tan ^{2}\left(k L^{*}\right)\right\} \quad \ldots \ldots
$$

ここで $S, S_{p}$ はそれぞれ主管と枝管の断面積(ここで は $\left.S=S_{p}\right) . L^{*}$ は枝管長さ (補正有り), $k$ は波数 $(=\omega / c)$ である。実験值と理論值は比較的よく合っており, 枝 管下流配管が長い, すなわち無反射端部とみなせる本 件では透過損失の評価でよいと言える。

\subsection{2 次用岐管のみ}

図 7 に制御室の騒音, 枝管結合部および枝管先端部 

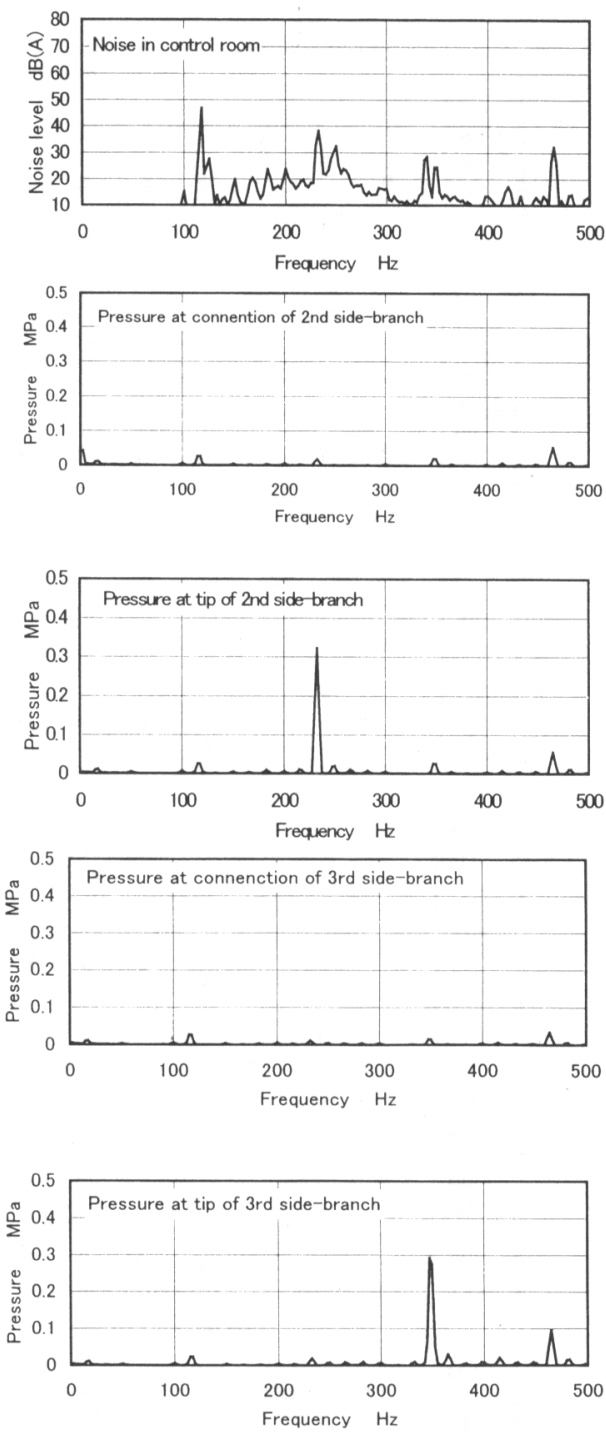

Fig. 8 Spectra of noise and pressures with side branches for $2^{\text {nd }}(\mathrm{B})$ and $3^{\text {rd }}\left(\mathrm{B}^{\prime}\right)$ components

の圧力脈動の周波数分析結果を示す。これらをみると 結合部の圧力脈動 2 次成分は枝管が無い場合に比べ非 常に小さくなっている.しかし先端部のそれは大きい. 一方 3 次成分の結合部圧力は枝管が無い場合に比べて 大きくなっている。これらは次のように説明できる。

まず 2 次成分について言えば， 2 次用枝管を用いて いるので結合部の圧力脈動は理論的には０になる（反 射波は入射波に対して半波長遅れるため)。次に 3 次成 分について言えば，先端部の圧力 $(0.654 \mathrm{MPa})$ は理 論的には入射圧力の 2 倍であるから，入射波の圧力は

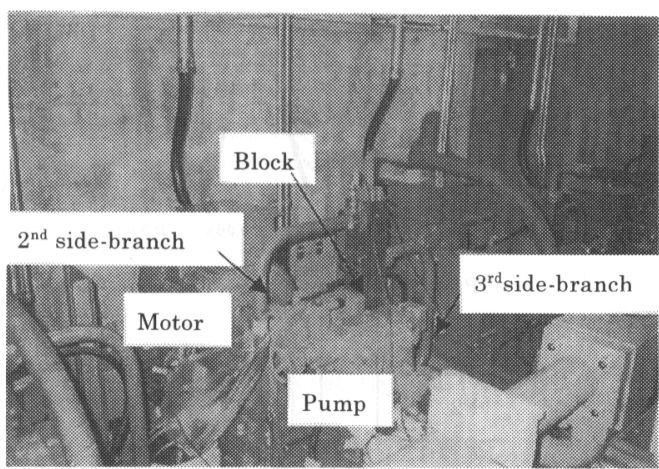

Fig.9 Application of $2^{\text {nd }}$ and $3^{\text {rd }}$ side-branches
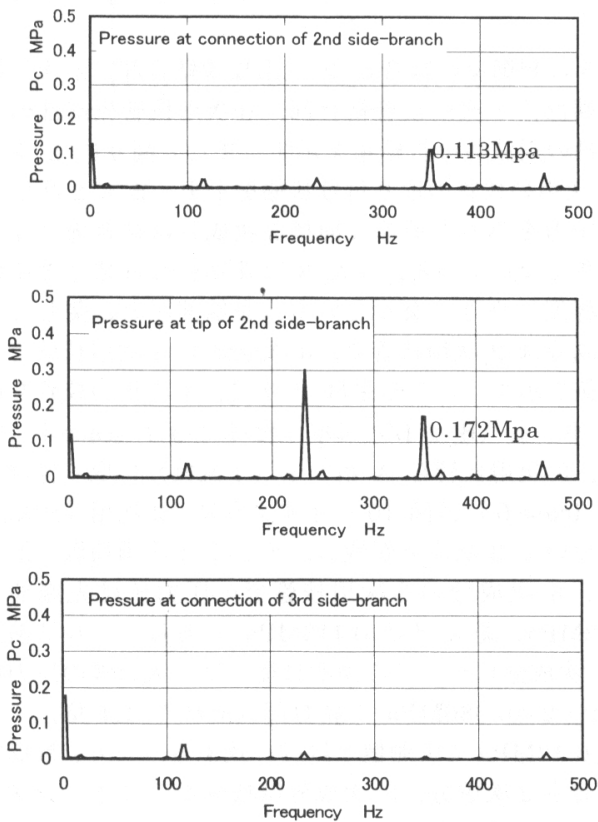

Fig.10 Spectra of pressures with side branches for $2^{\text {nd }}(\mathrm{B})$ and $3^{\text {rd }}(\mathrm{A})$ components

$0.327 \mathrm{MPa}$ となる. 反射波の入射波に対する位相は 3 $\pi / 2$ であり結合部では入射波と反射波がベクトル合成 されるので入射波の 1.4 倍，すなわち $0.458 \mathrm{MPa}$ とな る、結合部の実測值は $0.43 \mathrm{MPa}$ であるので枝管内で入 射波と反射波の干渉が生じていることが伺える。一方， 制御室の騒音も 2 次成分は枝管無しに比べ $35 \mathrm{~dB}$ も さくなっている，2次成分において Ptの成分が大きい のは, 図 3 の 2 次成分の圧力值 (これは枝管入射圧力 とみなされる） $0.15 \mathrm{MPa}$ のほぼ 2 倍 $(0.33 \mathrm{MPa})$ にな っているためである。

\subsection{2 次用岐管 +3 次用岐管}




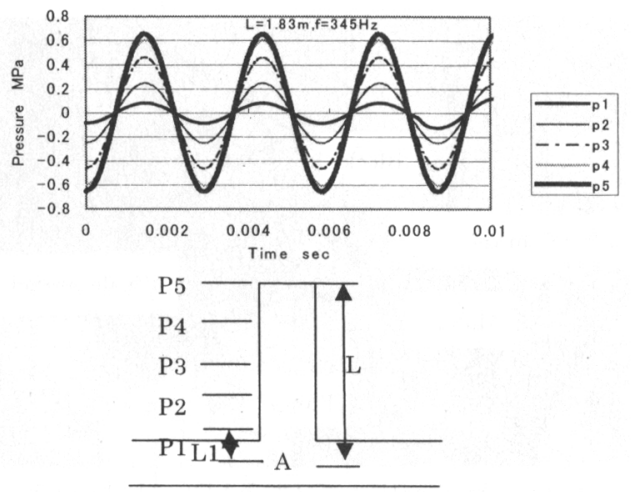

Fig.11 Wave form of pressure at each position

図 8 に制御室の騒音と 2 次用枝管結合部, 2 次用枝 管先端部， 3 次用枝管結合部，3 次用枝管先端部の圧 力脈動の周波数分析結果を示す。また, 図 9 に 2 次用 と 3 次用の枝管の取り付け状態を示す。まず 2 次用枝 管の圧力をみると前節と同様 2 次成分は結合部で非常 に小さくなっている。また 3 次成分も 2 次成分とほぼ 同じ程度に小さくなっている。先端部圧力に関しては 2 次成分は 2 次用枝管で, 3 次成分は 3 次用枝管で大 きな值を示す。この結果は 2 次用， 3 次用の枝管を同 じ B ポート（Bと B'）に取り付けた場合（case 4) で あり，3 次用枝管を $\mathrm{A}$ ポート（下流側）に取り付けた 場合 (case 6) は図 10 に示すように，2 次用枝管結合 部において 3 次成分が残る。そして 3 次用枝管で消さ れる. 3 次成分の 2 次用枝管での圧力值は先端部で $0.172 \mathrm{MPa}$, 結合部で $0.113 \mathrm{MPa}$ である。これは前節 の 3 次成分についての説明に従えば，入力波の圧力は $0.172 / 2=0.086 \mathrm{MPa}$ で結合部はそれの 1.4 倍，すな わち $0.12 \mathrm{MPa}$ で実測值とほほ一致する。一方、制御室 の騷音も 2 次成分, 3 次成分は枝管なしに比べ非常に 小さくなっている.

\section{5. 先端部と結合部の振幅比と位相差}

4.2 節で述べたように先端部の圧力振幅 $\hat{p} 5$ （図 11 参 照）は枝管入射圧力の 2 倍であることから, 結合部の 圧力の計測值 $p 1$ は次式で計算できる：ただし，L1は図 11 に示す長さで, $L 2$ は $L 2=2 L-L 1$ であり, 位相の基 準を図 11 下図のA.点にとる。

$p 1=(\hat{p} 5 / 2) \sin (\omega t-k L 1)+(\hat{p} 5 / 2) \sin (\omega t-k L 2)$ $=(\hat{P} 5 / 2)[(\cos k L 1+\cos k L 2) \sin \omega t-(\sin k L 1+\sin k L 2) \cos \omega t]$

$=A \sin \left(\omega t-\phi_{1}\right)$

ここて

$A=\hat{p} 5 \cos k(L-L 1)$

$\phi_{1}=\tan ^{-1}\left(\frac{\sin k L 1+\sin k L 2}{\cos k L 1+\cos k L 2}\right)=\tan ^{-1}(\tan k L)=k L+n \pi$
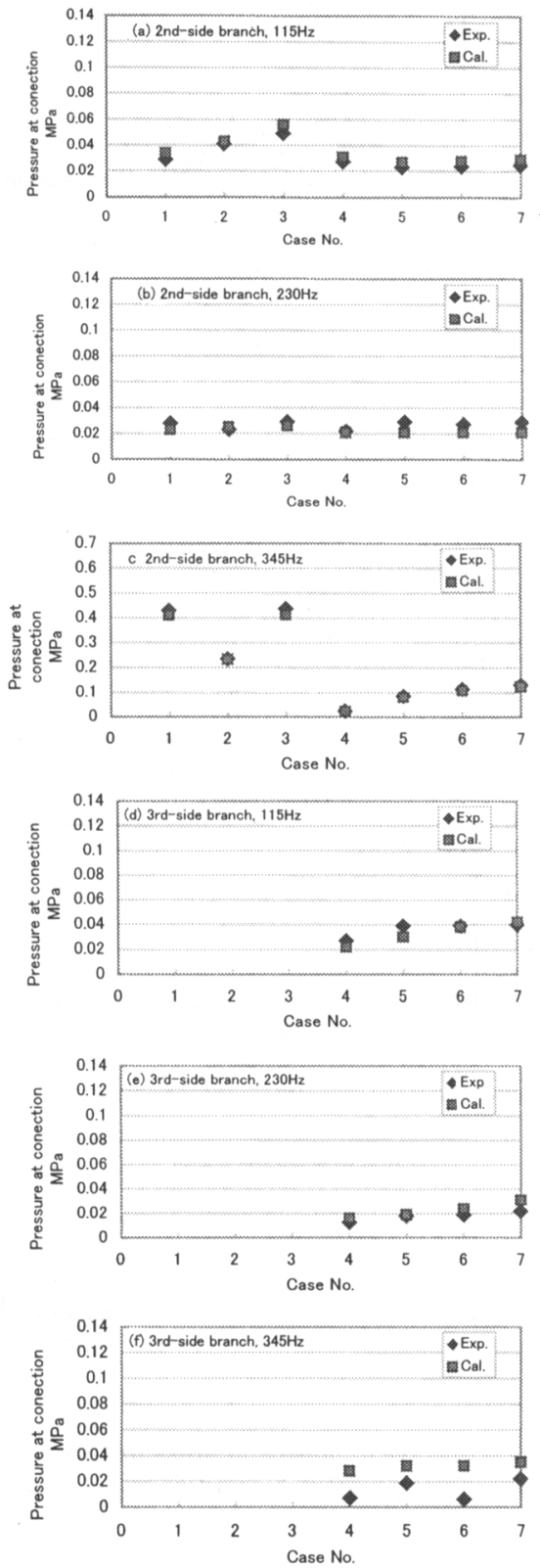

Fig.12 Comparison between cal. And Meas.

$p 5=\hat{p} 5 \sin (\omega t-k L)=\hat{p} 5 \sin \left(\omega t-\phi_{5}\right) \quad$ つま $\phi_{5}=k L \cdots$

したがって式(4)、(5)より $p 1$ と $p 5$ の位相差は同相か逆 相である。

また、枝管の効果が最大となる周波数では式（3）は

$A=\hat{p} 5 \cos \left(\frac{\pi}{2}\left(1-\frac{L 1}{L}\right)\right)$ 
となるから，共鳴モードと同じ音圧分布となる。しか しながら圧力低減メカニズムは共鳴ではなく音波の単 なる干渉である。なぜなら式(5)および以下に示す実験 結果で示されるように枝管先端部の圧力が枝管入射圧 力の 2 倍にしか成らないからである。一方共鳴現象で あれば枝管先端部の圧力は励振エネルギと減衰エネル ギがつりあうまで大きくなるはずである。

圧力変動の計算結果の一例を図 11 に示す。これは 2 次 用枝管を 4 等分し, 先端の圧力を $p 5$, 根元の圧力を $p 1$ とした場合の各位置に扔ける 3 次成分 $(345 \mathrm{~Hz})$ の圧 力波形である。本例では同相であり, 実験結果も同相 であった。

次に表 1 ，表 2 に示すケース 1 から 7 について式（2） を用いて計算した結合部圧力の結果と実測結果を図 12

（a）〜（f）に示す，いずれの場合も計算結果と実験 結果は非常によく一致しており, 枝管の圧力低減メ力 ニズムが単に位相の逆転によるものであることを示し ている.

\section{1 次用枝管における 2 次成分の圧力挙動}

一般に 1 次成分の圧力脈動を抑制する枝管を用いる と 1 次成分は抑制されるが 2 次成分は逆に共鳴を起こ して非常に大きな圧力変動を生成するように思われて いる。しかしながら吐出配管が非常に長い場合は全体 系としては無反射の条件が成り立つので共鳴は起こり 得ず，ただ単に枝管端部で反射した波と入射波とが同 相で重曽され，枝管下流部の圧力振幅は入射のそれの 2 倍となるに過ぎない。また枝管下流の配管が短く, し たがって反射端部となっている場合には透過損失の評 価は不適であり, 挿入損失で評価されなければならな い.この場合は

$$
\left(S_{p} / S\right) \tan (k L) \cdot \tan \left(k l_{2}\right)=1
$$

を満たす周波数で共鳴するのであり, $\tan (k L)=0$, すな わち $f=\mathrm{nc} / 2 L$ で共鳴するのではないことに注意すべき である、ここで $l_{2}$ は枝管下流配管長さであり，上流側 配管長さはそれに比べて非常に小さいと仮定している.

図 13 は表 3 に示す種々の長さの 1 次用枝管を取り付 け, 結合部における 2 次成分 $(230 \mathrm{~Hz})$ の圧力を式 $(2)$ を用いて計算した值と実測値を比較したものである。 この図よりいずれのケースでも両者はほとんどー致し ており，1 次用枝管を用いた場合の 2 次成分は入力压 力の高々 2 倍の圧力になるにすぎないことが示された.

\section{7. 結 言}

油圧ポンプの圧力脈動に起因する振動・騒音を低減す るために，枝管の適用を図ったところ，以下の知見が 得られた。

（1）枝管の圧力脈動低減効果はきめ細かなチューニ

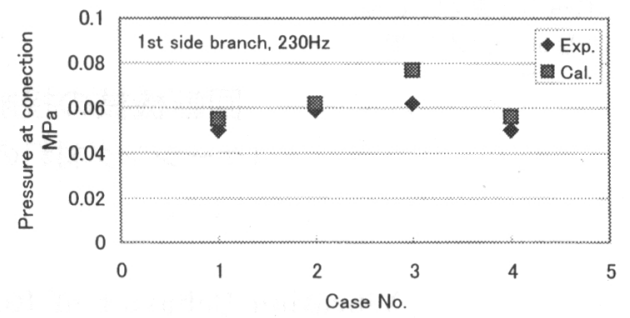

Fig.13 Comparison bet. Exp.and Cal. of Pc

Table.3 Cases of $1^{\text {st }}$-side-branch

\begin{tabular}{|c|c|c|c|}
\hline Case & Block & Port & Length \\
\hline 1 & Long & B & $3.66 \mathrm{~m}$ \\
\hline 2 & Long & B & $3.46 \mathrm{~m}$ \\
\hline 3 & Long & B & $3.86 \mathrm{~m}$ \\
\hline 4 & Long & B & $3.26 \mathrm{~m}$ \\
\hline
\end{tabular}

ングを行うことで劇的な効果 $(35 \mathrm{~dB})$ をもたら すことが実機で確認された。

(2) 2 次分岐管と 3 次分岐管を対向して設置するとそ の下流で 2 次成分と 3 次成分の圧力脈動が同時 に低減されるが, タンデム配置にすると上流に置 かれた枝管特性による低減効果から順に現われ る.

（3）無反射の境界条件が成り立つ配管における枝管 の低減メカニズムは, 枝管から主管にもどる反 射圧力脈動と枝管への入射圧力脈動の位相差が 180 度 (反転) となるためで, 従来の考え方の 妥当性が多くの実験により再確認できた．

(4) ある周波数 $f$ で効果のある枝管は $2 f$ の成分では 共鳴を起こし問題があると考えられがちである が，そのようなことは起こりえず，単に位相が 同じとなり，圧力振幅が 2 倍になるに過ぎない.

（5）枝管より下流の配管が短く, 出口境界で反射す る系にあっては共鳴するが, その共鳴周波数は 枝管単体のそれではなく，系全体のそれである.

\section{文献}

(1) 福田 · 奥田, “騒音対策と消音設計”, 共立出版, (1973), p209

（2）時田保夫監修，“音の環境と制御技術，第 1 巻基 礎技術”，(2000), p417

（3）小嶋 · 松原 · 須藤, 機論, $61-583$, B (1995), 1005.

（4）小嶋 - 一柳, 機論, $61-583$, B (1995), 230.

(5) 小鴆· 木村·寺沢 ·竹下, 機論, 641-621, B (1998), 120.

（6）機械工学便覧, 改定第 5 版, 第 8 章, 8-2 